\title{
Morphology, morphogenesis and phylogeny of the new soil ciliate, Bistichella granulifera n. sp. (Protista, Ciliophora)
}

\author{
Zhao Lyu \\ Northwest University \\ Jingbao Li \\ Northwestern Polytechnical University \\ Yurui Wang \\ Shaanxi Normal University \\ Jiyang Ma \\ Shaanxi Normal University \\ Chen Shao ( $\nabla$ shaochen@snnu.edu.cn ) \\ Shanxi Normal University https://orcid.org/0000-0001-8474-3204
}

\section{Research article}

Keywords: Bistichella, Novel species, Ontogeny, Phylogenetic, SSU rDNA

Posted Date: August 28th, 2020

DOl: https://doi.org/10.21203/rs.3.rs-48003/v1

License: @ (1) This work is licensed under a Creative Commons Attribution 4.0 International License. Read Full License 


\section{Abstract}

Background: Hypotrichous ciliates are showing extremely morphological diverse and complicated morphogenesis. However, many hypotrichs are still unknown/poorly-known and need to be explored. Recently, Foissner (2016) reassigned the species in Bistichella and Parabistichella. Due to lack of morphological and morphogenetic information, some problems were overlooked. In present work, a new species, Bistichella granulifera $\mathrm{n}$. sp., was found in northern China. Based on its infraciliature, ontogenesis analyses and phylogenetic study, the phylogenetic position of Bistichella was discussed.

Results: Bistichella granulifera n. sp. was characterized by having elongated oval body, two macronuclear nodules, cortical granules present, three frontal and three or four buccal cirri, three frontal rows with seven to ten cirri, usually two frontoventral rows with the left one usually terminates at $90 \%$ down length of body and no breaks in the right one. The main morphogenetic features of the novel species were as follows: (1) the posterior part of the old adoral membranelles is renewed; (2) frontoventral-transverse cirral anlagen III to $\mathrm{V}$ each form a frontal row, and anlagen $\mathrm{VI}$ to $\mathrm{n}$ each produce a frontoventral row; (3) both marginal rows and dorsal kineties develop intrakinetally; (4) the macronuclear nodules fuse to form a single mass. The gene sequence of Bistichella was investigated for the first time. Phylogenetic analyses based on the SSU rDNA sequences showed that the Bistichella groups with the non-dorsomarginalian hypotrichs.

Conclusions: Morphology, morphogenesis and phylogenetic position of Bistichella granulifera n. sp., was investigated. Each frontoventral row originates from one anlage and only three bipolar dorsal kineties are present in the new species, which means it should belong to non-Dorsomarginalia rather than Amphisiellidae. Even though Bistichella has a close relationship with amphisiellids, due to the limited gene sequence, the phylogenetic position of Bistichella needs more data to be fully understood.

\section{Background}

Hypotrichous ciliates are a highly differentiated group within ciliated protists, and have diversified morphological features and complicated morphogenetic processes [1-8]. To date, many studies have been carried out on the classification and phylogeny of hypotrichs [9-14].

The genus Bistichella was originally established by Berger (2008) [1]. Later, mainly due to the presence or absence of transverse cirri, Foissner (2016) [4] reorganized the species in Bistichella and Parabistichella, and amended the diagnosis of Bistichella as follows: two or three short frontal cirral rows and two or three long frontoventral cirral rows, three or four enlarged frontal cirri, more than one buccal cirrus, dorsal kineties in a Gonostomum-pattern, transverse cirri and caudal cirri lacking [4]. To date, four species have been assigned to Bistichella, namely B. buitkampi (Foissner, 1982) Berger, 2008 (type species), B. humicola (Gellért, 1956) Berger, 2008, B. chilensis Foissner, 2016, and B. kenyaensis Foissner, 2016 [1, 4, 15, 16]. However, morphogenetic data in Bistichella is still lacking and the gene sequence is unknown.

In this work, a novel soil ciliate Bistichella granulifera n. sp. was isolated from Jiangjunshan ancient town, Xi'an, northern China. Observations of its morphology and morphogenetic characteristics demonstrate that it represents a new member of the genus Bistichella. The phylogenetic position of Bistichella was also investigated.

\section{Results}

\section{Zoobank registration.}

Present work: urn:Isid:zoobank.org:pub:8AFC5FAA-C4F5-4956-8FFD-41AC2A0C60BF

\section{Bistichella granulifera n. sp.}

\section{Zoobank registration.}

Bistichella granulifera n. sp.: urn:Isid:zoobank.org:act:4F8D4B63-63DB-41D7-B06F-8E22FD5F68E5

Diagnosis. Size about 110-160 × 40-60 um in vivo. Body elongate oval. Two macronuclear nodules. Single contractile vacuole located near mid-left of body. Cortical granules colourless, about $1 \mu \mathrm{m}$ across, densely scattered throughout cell surface. 33-38 adoral membranelles, three enlarged frontal cirri and three or four buccal cirri arranged in a row. Three frontal rows, composed about 
three cirri in each. Two to four frontoventral rows extending to the posterior of the body. 38-48 and left and 48-54 right marginal cirri. Three bipolar dorsal kineties. Soil habitat.

Type slides. The protargol slide with the holotype specimen (accession number: LZ2016041701A) and another two paratype slides (accession number: LZ2016041701B, C) have been deposited in the Laboratory of Protozoological Biodiversity and Evolution in Wetland, Shaanxi Normal University, China. The holotype specimen (Fig. 1g, h and Fig. 2j, k) was marked on the back of the slide [17, 18].

Type locality. Soil in Jiangjunshan ancient town (3402'16"N; 10904'53"E), Xi'an, China.

Etymology. The species-group name 'granulifera' refers to having cortical granules, which is a main feature of the species. Female gender.

\section{Morphology of Bistichella granulifera n. sp. (Fig. 1 and Fig. 2; Table 1)}

Table 1 Morphometric characterization of Bistichella granulifera n. sp. based on protargol-stained specimens (measurements in $\mu$ m).

\begin{tabular}{|c|c|c|c|c|c|c|c|c|}
\hline Character & HT & Min & Max & Med & Mean & SD & $\mathrm{CV}$ & $\mathrm{n}$ \\
\hline Body, length & 128 & 117 & 179 & 136 & 141 & 19.69 & 14 & 10 \\
\hline Body, width & 51 & 45 & 68 & 52 & 55 & 8.05 & 15 & 10 \\
\hline Body length:width ratio & 2.51 & 2.02 & 2.96 & 2.64 & 2.58 & 0.32 & 12 & 10 \\
\hline AZM, length & 41 & 36 & 53 & 44 & 44 & 5.45 & 12 & 10 \\
\hline AZM/body length & 0.32 & 0.28 & 0.33 & 0.32 & 0.31 & 0.02 & 5 & 10 \\
\hline DE-value & 0.21 & 0.19 & 0.28 & 0.24 & 0.24 & 0.03 & 13 & 10 \\
\hline Number of adoral membranelles & 33 & 33 & 38 & 36 & 35 & 1.51 & 4 & 10 \\
\hline Number of enlarged frontal cirri & 3 & 3 & 3 & 3 & 3 & 0 & 0 & 10 \\
\hline Number of buccal cirri & 3 & 3 & 4 & 3 & 3 & 0.52 & 17 & 10 \\
\hline Number of frontal rows & 3 & 3 & 3 & 3 & 3 & 0 & 0 & 10 \\
\hline Number of cirri in frontal row I & 3 & 2 & 3 & 3 & 3 & 0.52 & 17 & 10 \\
\hline Number of cirri in frontal row II & 3 & 2 & 3 & 3 & 3 & 0.32 & 11 & 10 \\
\hline Number of cirri in frontal row III & 4 & 3 & 4 & 4 & 4 & 0.48 & 12 & 10 \\
\hline Number of frontoventral rows & 2 & 2 & 4 & 2 & 2 & 0.62 & 21 & 10 \\
\hline Number of cirri in frontoventral row I & 32 & 26 & 37 & 31 & 31 & 3.78 & 12 & 10 \\
\hline Number of cirri in frontoventral row II & 40 & 14 & 44 & 29 & 29 & 10.82 & 37 & 10 \\
\hline Number of cirri in frontoventral row III & - & 21 & 41 & 35 & 32 & - & - & 5 \\
\hline Number of cirri in frontoventral row IV & - & 21 & 29 & 25 & 25 & - & - & 2 \\
\hline Number of cirri in left marginal row & 44 & 38 & 48 & 46 & 45 & 3.36 & 7 & 10 \\
\hline Number of cirri in right marginal row & 48 & 48 & 54 & 49 & 50 & 2.27 & 5 & 10 \\
\hline Number of dorsal kineties & 3 & 3 & 3 & 3 & 3 & 0 & 0 & 10 \\
\hline Number of dikinetids in dorsal kinety 1 & 25 & 24 & 30 & 26 & 27 & 2.01 & 8 & 10 \\
\hline Number of dikinetids in dorsal kinety 2 & 24 & 24 & 27 & 26 & 26 & 1.16 & 4 & 10 \\
\hline Number of dikinetids in dorsal kinety 3 & 25 & 25 & 29 & 27 & 27 & 1.35 & 5 & 10 \\
\hline Number of macronuclear nodules & 2 & 2 & 2 & 2 & 2 & 0 & 0 & 10 \\
\hline Length of anterior macronuclear nodule & 26 & 26 & 44 & 30 & 31 & 5.95 & 20 & 10 \\
\hline Width of anterior macronuclear nodule & 9 & 8 & 16 & 11 & 11 & 2.75 & 26 & 10 \\
\hline Number of micronuclei & 2 & 2 & 3 & 2 & 2 & 0.32 & 16 & 10 \\
\hline Diameter of micronuclei & 3 & 3 & 4 & 3 & 3 & 0.32 & 11 & 10 \\
\hline
\end{tabular}

Abbreviations: AZM, adoral zone of membranelles; CV, coefficient of variation in \%; for the DE-value, see Berger (2006) for explanation; DK, dorsal kineties; HT, holotype specimen (also included in the sample n); Max, maximum; Mean, arithmetic mean; Med, median value; Min, minimum; n, number of specimens; SD, standard deviation.

Size was $110-160 \times 40-60 \mu \mathrm{m}$ in vivo $(n=5)$, about $141 \times 55 \mu \mathrm{m}$ on average in protargol impregnation with a ratio of length to width about 2.6:1. Body elongated oval with anterior and posterior ends narrowly and widely rounded respectively, both margins slightly convex, flexible and not contractile (Fig. 1a, g, h and Fig. 2a-c, j, k). Constantly two ellipsoidal macronuclear nodules, about $31 \times 11$ $\mu \mathrm{m}$ after protargol impregnation, arranged slightly left of the midline (Fig. 1h and Fig. 2h, j). About two globular micronuclei, located near the macronuclear nodules. Contractile vacuole located slightly ahead of mid-body near left margin, about $18 \mu \mathrm{m}$ across when fully extended (Fig. 1a). Cortical granules densely scattered throughout cell surface, about $1 \mu \mathrm{m}$ in diameter without colour, (Fig. 1b 
and Fig. 2e). Cytoplasm transparent to grayish, contains many lipid droplets, refractive globules and food vacuoles containing small ciliates and bacteria (Fig. 1a and Fig. 2d, i). Locomotion by slowly crawling on substrate or swimming by rotating around the longitudinal axis.

Adoral zone occupied about $31 \%$ of the cell length with the distal end extending to the right side; composed $33-38$ membranelles, (Fig. $1 \mathrm{~g}$ and Fig. 2f); largest base of membranelles about 8-15 $\mu \mathrm{m}$ long, cilia about $18 \mu \mathrm{m}$ long in vivo. Paroral and endoral curved anteriorly, and intersect optically near $1 / 3$ to middle of buccal area (Fig. 1g and Fig. 2f, j).

Consistently three enlarged frontal cirri with cilia about $15 \mu \mathrm{m}$ long in vivo. Three to four buccal cirri arranged in a longitudinal row right of the paroral. Three frontal rows, about three or four cirri in each. Frontal rows I and II located at the same level as the buccal cirral row, while frontal row III was a little behind and extends nearly to the proximal end of the adoral zone (Fig. 1g and Fig. 2f). Half of investigated specimens have two frontoventral rows, which are composed of 28-37 and 32-44 cirri. Frontoventral row I started from the level of mid-buccal area, extending slightly obliquely to about $90 \%$ of body length. Frontoventral row II started near the anterior end of the distal end of the adoral zone of membranelles (AZM), terminating at the same level as frontoventral row I (Fig. 1g). It is noteworthy that the patterns of frontoventral rows are rather variable in these specimens. In five out of ten individuals, one or two extra frontoventral rows present, short or long (Fig. 1C-f). One left and one right marginal row composed of 38-48 and 48-54 cirri, respectively, not confluent posteriorly (Fig. 1g and Fig. 2j).

Constantly three bipolar dorsal kineties with about 27 dikinetids in each row; dorsal cilia about $3 \mu \mathrm{m}$ long in life (Fig. 1h and Fig. $2 \mathrm{~g}, \mathrm{k}$ ). Caudal cirri lacking.

\section{Morphogenesis (Fig. 3 and Fig. 4)}

Only four dividers in different stages of morphogenesis during binary fission were found and the main morphogenetic features are described as follows:

Stomatogenesis and frontoventral-transverse cirral anlagen. In the early divider, the oral primordium are differentiated from anterior to posteriad to form new adoral membranelles in the opisthe; two sets of frontoventral-transverse cirral anlagen are recognizable, and the old frontal and frontoventral rows contribute to the anlagen (Fig. 3a and Fig. 4a). The undulating membranes anlage (UM-anlage = anlage I) appears in each daughter cell (Fig. 3a). The posterior portion of the old AZM is renewed (Fig. 3a and Fig. 4b).

Later, in the middle divider, the new adoral membranelles continue to differentiate in the opisthe, and the leftmost frontal cirrus is derived from the anterior end of anlage I in both dividers (Fig. 3c and Fig. 4d). The proximal membranelles of the old AZM are replaced by new membranelles (Fig. 3c, e and Fig. 4d). All cirral anlagen begin to fragmentize and develop into new cirri (Fig. 3e and Fig. 4f). The cirrus from anlage I together with the anterior-most cirri from anlagen II and III form the three enlarged frontal cirri. A row of buccal cirri is derived from anlage II and migrates near to the new paroral. Cirri from anlagen III to V form three frontal rows, and anlagen VI to $\mathrm{n}$ each produces a frontoventral row. Also, additional anlagen are present, which may contribute the additional long or short ventral rows (Fig. 3c, e, g and Fig. 4d, f).

In a late divider, the differentiation of membranelles is completed, and the anterior end of the newly AZM bends to the right in the opisthe. The UM-anlage splits longitudinally to form the paroral and endoral. The new cirri migrate to their final positions and replace the parental structures (Fig. $3 g$ and Fig. 4g).

Development of marginal rows and dorsal kineties. The formation of the marginal rows and dorsal kineties proceeds intrakinetally that some old cirri within each parental row dedifferentiate and form the anlagen. These anlagen then stretch longitudinally and replace the parental structures completely (Fig. 3a-h and Fig. 4a, c, g, h).

Division of nuclear apparatus. Two macronuclear nodules fuse to form a single mass during the middle stage and then divide to form two nodules for both dividers. Micronuclei divide mitotically (Fig. 3b, d, f, h and Fig. 4e).

\section{Phylogenetic analyses based on SSU rDNA sequences (Fig. 5)}

The length and GC content of the SSU rDNA sequence of Bistichella granulifera $\mathrm{n}$. sp. (GenBank accession number: MT604042) are $1676 \mathrm{bp}$ and $46.12 \%$, respectively. Phylogenetic trees were inferred from the SSU rDNA sequences using two different methods (ML 
and $\mathrm{BI}$ ), and the topologies of two trees were basically congruent. Therefore, only the $\mathrm{ML}$ tree with bootstraps and posterior probabilities from both algorithms is presented (Fig. 5).

In the phylogenetic trees, Bistichella granulifera n. sp. forms a large clade with species in the genera Uroleptoides, Parabistichella, Orthoamphisiella, Lamtostyla, Keronopsis, Paraholosticha and Pseudokahliella with low support (14\% ML, 0.32 BI). The sequence similarity between $B$. granulifera $\mathrm{n}$. sp. and the species in this clade ranges from $92.1 \%$ to $99.1 \%$ (Table 2 ).

Table 2 Percentages of sequence identity (lower left) and pairwise distance (upper right) based on SSU rDNA sequences between Bistichella granulifera n. sp. and the species which formed a big clade with the new species in Fig. 5. 


\begin{tabular}{|c|c|c|c|c|c|c|c|c|c|c|c|c|c|c|c|c|}
\hline Species & 1 & 2 & 3 & 4 & 5 & 6 & 7 & 8 & 9 & 10 & 11 & 12 & 13 & 14 & 15 & 16 \\
\hline $\begin{array}{l}1 \text { Uroleptoides } \\
\text { magnigranulosus } \\
\text { AM412774 }\end{array}$ & & 0.000 & 0.000 & 0.001 & 0.003 & 0.003 & 0.002 & 0.001 & 0.002 & 0.002 & 0.003 & 0.003 & 0.003 & 0.004 & 0.009 & 0.020 \\
\hline $\begin{array}{l}2 \quad \text { Uroleptoides } \\
\text { longiseries } \\
\text { MH143251 }\end{array}$ & 0.968 & & 0.000 & 0.001 & 0.003 & 0.003 & 0.002 & 0.001 & 0.002 & 0.002 & 0.003 & 0.003 & 0.003 & 0.004 & 0.009 & 0.020 \\
\hline $\begin{array}{l}3 \text { Parabistichella } \\
\text { multilineae } \\
\text { MK265247 }\end{array}$ & 0.888 & 0.916 & & 0.001 & 0.003 & 0.003 & 0.002 & 0.001 & 0.002 & 0.002 & 0.003 & 0.003 & 0.003 & 0.004 & 0.009 & 0.020 \\
\hline $\begin{array}{l}4 \text { Parabistichella } \\
\text { variabilis } \\
\text { JN008943 }\end{array}$ & 0.998 & 0.968 & 0.887 & & 0.005 & 0.005 & 0.003 & 0.003 & 0.003 & 0.002 & 0.005 & 0.005 & 0.004 & 0.005 & 0.009 & 0.020 \\
\hline $\begin{array}{l}5 \\
\text { Orthoamphisiella } \\
\text { breviseries } \\
\text { AY498654 }\end{array}$ & 0.996 & 0.966 & 0.886 & 0.995 & & 0.003 & 0.003 & 0.002 & 0.001 & 0.003 & 0.004 & 0.004 & 0.003 & 0.002 & 0.007 & 0.017 \\
\hline $\begin{array}{l}6 \\
\text { Orthoamphisiella } \\
\text { namibiense } \\
\text { JQ723974 }\end{array}$ & 0.993 & 0.962 & 0.885 & 0.992 & 0.994 & & 0.003 & 0.002 & 0.001 & 0.003 & 0.004 & 0.004 & 0.003 & 0.003 & 0.008 & 0.020 \\
\hline $\begin{array}{l}7 \quad \text { Bistichella } \\
\text { granulifera n. sp. } \\
\text { MT604042 }\end{array}$ & 0.960 & 0.954 & 0.921 & 0.959 & 0.960 & 0.956 & & 0.001 & 0.001 & 0.001 & 0.003 & 0.003 & 0.002 & 0.003 & 0.008 & 0.018 \\
\hline $\begin{array}{l}8 \quad \text { Lamtostyla } \\
\text { salina } \mathrm{KX641150}\end{array}$ & 0.968 & 0.962 & 0.915 & 0.967 & 0.968 & 0.964 & 0.988 & & 0.001 & 0.001 & 0.002 & 0.002 & 0.001 & 0.003 & 0.008 & 0.019 \\
\hline $\begin{array}{l}9 \quad \text { Keronopsis } \\
\text { helluo KY492516 }\end{array}$ & 0.927 & 0.930 & 0.953 & 0.927 & 0.928 & 0.925 & 0.965 & 0.955 & & 0.001 & 0.003 & 0.003 & 0.002 & 0.002 & 0.007 & 0.018 \\
\hline $\begin{array}{l}10 \\
\text { Paraholosticha } \\
\text { pannonica } \\
\text { KY492517 }\end{array}$ & 0.927 & 0.930 & 0.953 & 0.928 & 0.927 & 0.924 & 0.965 & 0.955 & 0.998 & & 0.003 & 0.003 & 0.002 & 0.003 & 0.007 & 0.020 \\
\hline $\begin{array}{l}11 \\
\text { Parabistichella } \\
\text { xui HQ699895 }\end{array}$ & 0.994 & 0.964 & 0.886 & 0.994 & 0.994 & 0.991 & 0.958 & 0.967 & 0.927 & 0.927 & & 0.003 & 0.002 & 0.003 & 0.007 & 0.019 \\
\hline $\begin{array}{l}12 \\
\text { Parabistichella } \\
\text { cystiformans } \\
\text { KJ509196 }\end{array}$ & 0.960 & 0.954 & 0.917 & 0.959 & 0.960 & 0.958 & 0.991 & 0.988 & 0.959 & 0.959 & 0.960 & & 0.002 & 0.003 & 0.008 & 0.020 \\
\hline $\begin{array}{l}13 \text { Lamtostyla } \\
\text { ovalis KP266625 }\end{array}$ & 0.995 & 0.965 & 0.886 & 0.994 & 0.995 & 0.993 & 0.958 & 0.967 & 0.927 & 0.927 & 0.995 & 0.963 & & 0.003 & 0.008 & 0.019 \\
\hline $\begin{array}{l}14 \\
\text { Parabistichella } \\
\text { dieckmanni } \\
\text { MN994505 }\end{array}$ & 0.974 & 0.968 & 0.902 & 0.973 & 0.976 & 0.974 & 0.974 & 0.983 & 0.944 & 0.942 & 0.976 & 0.978 & 0.976 & & 0.005 & 0.018 \\
\hline $\begin{array}{l}15 \\
\text { Paraholosticha } \\
\text { muscicola } \\
\text { KT003281 }\end{array}$ & 0.894 & 0.922 & 0.975 & 0.894 & 0.896 & 0.894 & 0.930 & 0.923 & 0.938 & 0.938 & 0.896 & 0.926 & 0.895 & 0.915 & & 0.018 \\
\hline $\begin{array}{l}16 \\
\text { Pseudokahliella } \\
\text { marina } \\
\text { KM222095 }\end{array}$ & 0.976 & 0.946 & 0.870 & 0.976 & 0.979 & 0.978 & 0.941 & 0.949 & 0.910 & 0.909 & 0.978 & 0.943 & 0.978 & 0.962 & 0.886 & \\
\hline
\end{tabular}




\section{Morphological comparison with congeners (Table 3)}

Table 3 Morphological comparison of Bistichella granulifera n. sp. with its congeners.

\begin{tabular}{|c|c|c|c|c|c|}
\hline Characteristic & $\begin{array}{c}B . \\
\text { granulifera n. } \\
\text { sp. }\end{array}$ & B. buitkampi & B. chilensis & B. humicola & B. kenyaensis \\
\hline Body shape & $\begin{array}{c}\text { Elongated } \\
\text { oval }\end{array}$ & $\begin{array}{l}\text { Slightly dumbbell- } \\
\text { shaped to } \\
\text { sigmoidal }\end{array}$ & $\begin{array}{l}\text { Slenderly ellipsoid } \\
\text { to almost } \\
\text { rectangular }\end{array}$ & $\begin{array}{l}\text { Elongate ellipsoid with } \\
\text { margins converging } \\
\text { posteriorly }\end{array}$ & $\begin{array}{l}\text { Ellipsoid to slenderly ellipsoid, but } \\
\text { usually widest anterior of mid- } \\
\text { body }\end{array}$ \\
\hline Cortical granules & Present & Absent & Absent & $\mathrm{N} / \mathrm{A}$ & Absent \\
\hline $\begin{array}{l}\text { Adoral } \\
\text { membranelles, } \\
\text { number }\end{array}$ & $33-38$ & $34-40$ & $25-38$ & 31 & $21-30$ \\
\hline $\begin{array}{l}\text { Frontal cirri, } \\
\text { number }\end{array}$ & 3 & 3 & 4 & 3 & 3 \\
\hline $\begin{array}{l}\text { Buccal cirri, } \\
\text { number }\end{array}$ & 3 or 4 & $2-4$ & $4-6$ & 1 & 2 or 3 \\
\hline $\begin{array}{l}\text { Frontal rows, } \\
\text { number }\end{array}$ & 3 & 1 or 2 & 2 or 3 & 1 & 2 or 3 \\
\hline $\begin{array}{l}\text { Frontal rows, } \\
\text { number of cirri }\end{array}$ & $7-10$ & $2-10$ & $6-13$ & 9 & $4-6$ \\
\hline $\begin{array}{l}\text { Termination of } \\
\text { frontoventral } \\
\text { row I }\end{array}$ & $\begin{array}{l}90 \% \text { down } \\
\text { length of } \\
\text { body }\end{array}$ & $\begin{array}{c}75 \% \text { down } \\
\text { length of body }\end{array}$ & $\begin{array}{c}76 \% \text { down } \\
\text { length of body }\end{array}$ & $64 \%$ down length of body & $54 \%$ down length of body \\
\hline $\begin{array}{l}\text { Frontoventral } \\
\text { row I, number of } \\
\text { cirri }\end{array}$ & $26-37$ & $25-37$ & $16-33$ & $24 *$ & $9-20$ \\
\hline $\begin{array}{l}\text { Frontoventral } \\
\text { row II }\end{array}$ & $\begin{array}{c}\text { Not } \\
\text { interrupted }\end{array}$ & Interrupted & Interrupted & Not interrupted & Interrupted \\
\hline $\begin{array}{l}\text { Right marginal } \\
\text { row, number of } \\
\text { cirri }\end{array}$ & $48-54$ & $39-49$ & $29-55$ & 41 & $30-43$ \\
\hline $\begin{array}{l}\text { Macronuclear } \\
\text { nodules, number }\end{array}$ & 2 & 4 & 2 or 3 & 32 & 2 \\
\hline Data source & $\begin{array}{l}\text { Present } \\
\text { study }\end{array}$ & $\begin{array}{c}\text { Foissner (1982) } \\
\text { Berger (2008) }\end{array}$ & Foissner (2016) & $\begin{array}{l}\text { Gellért (1956) } \\
\text { Berger (2008) }\end{array}$ & Foissner (2016) \\
\hline
\end{tabular}

* Data from illustration.

a Body size may be measured after fixation.

b A short cirral row included, which located in rear body portion.

Our new isolate matches Bistichella in almost all key features, i.e. three or four frontal cirri, two or three short frontal and two or three frontoventral rows, and more than one buccal cirrus, transverse cirri absent, dorsal kinety pattern of Gonostomum-type, etc. Up to now, four valid species of Bistichella are recognized, namely, B. buitkampi, B. humicola, B. chilensis and B. kenyaensis $[1,4,15,16]$.

Compared to the type species, Bistichella buitkampi, B. granulifera n. sp. can be distinguished by having more frontal rows (three vs. one or two), less macronuclear nodules (two vs. four), longer frontoventral row I (terminates at $90 \% \mathrm{vs.} 75 \%$ down length of body) and cortical granules present (vs. absent). Note that, in B. buitkampi, a short longitudinal cirral row in the rear portion of the body was termed transverse cirri in the original description $[1,15]$.

In terms of the infraciliature, Bistichella chilensis is closely related to B. granulifera $\mathrm{n}$. $\mathrm{sp}$. The former can be recognized by having body shape slenderly ellipsoid to almost rectangular (vs. elongated oval), four (vs. three) frontal cirri, a wide break in the right frontoventral row at mid-body (vs. no break), termination of frontoventral row I at $76 \%$ (vs. $90 \%$ ) down length of body and cortical granules absent (vs. present) [4].

Even though the morphology of Bistichella humicola is not very detailed, given present knowledge, B. granulifera $\mathrm{n}$. sp. can be easily separated with $B$. humicola by having not tapered tail (vs. slightly tapered), three or four (vs. only one) buccal cirri and three (vs. one) 
frontal rows, lower termination of frontoventral row I ( $90 \%$ vs. $64 \%$ down length of body) and less (two vs. 32 ) macronuclear nodules $[1,16]$.

Bistichella kenyaensis differs from the $B$. granulifera n. sp. by having body shape ellipsoid to slenderly ellipsoid, and usually widest anterior of mid-body (vs. elongated oval and widest at mid-body), the right frontoventral row with a very wide break in the middle quarters of body (vs. no break), fewer adoral membranelles (21-30 vs. 33-38) and cirri in the frontal rows (4-6 vs.7-10), frontoventral row I ( $9-20$ vs. $26-37$ ) and right marginal row (30-43 vs. $48-54)$, shorter frontoventral row I (terminates at $54 \%$ vs. $90 \%$ down length of body) and no cortical granules (vs. present) [4].

\section{Morphogenetic comparison}

The morphogenesis of Bistichella species is reported for the first time in present work. Based on the investigation, the main characteristic events during morphogenesis of the B. granulifera n. sp. can be summarized as follows: (1) in the proter, the posterior part of the parental AZM is renewed; in the opisthe; (2) frontoventral-transverse cirral anlagen III to $V$ each form a frontal row and anlagen VI to $\mathrm{n}$ each produces a frontoventral row; (3) the left and right marginal anlagen develop intrakinetally; (4) dorsal morphogenesis follows a typical Gonostomum-pattern; and (5) the macronuclear nodules fuse to form a single mass.

The genus Parabistichella resembles Bistichella in terms of forming a row of buccal cirri, marginal anlagen and dorsal kineties anlagen developing intrakinetally [1, 4, 19-22]. However, Bistichella can be distinguished by a lack of transverse cirri (vs. formed in Parabistichella) $[4,19,21]$. Another important morphogenetic feature is the origin of the frontoventral row. Hitherto, in Parabistichella, morphogenetic data is available for only three species, which are $P$. variabilis, $P$. cystiformans and $P$. dieckmanni. However, each frontoventral row is produced by one anlage in $P$. cystiformans, whereas the left frontoventral row originating from two anlagen in $P$. dieckmanni (morphogenesis is described very roughly in the type species, $P$. variabilis, so data unavailable) $[10,19,21,22] . B$. granulifera n. sp. shows similarity to $P$. cystiformans in that the frontoventral row originates from one anlage.

\section{Phylogenetic analyses}

Berger (2008) [1] classified Bistichella as incertae sedis in Hypotrichia. In the phylogenetic tree, Bistichella has a close relationship with stichotrichids (Fig. 5). Additionally, Bistichella falls into a clade which includes Uroleptoides, Parabistichella, Orthoamphisiella, Lamtostyla, Keronopsis, Paraholosticha and Pseudokahliella, and shares the same morphological features, i.e., at least one long or moderate long frontoventral row, one marginal cirral row on each side, constantly three bipolar dorsal kineties, and a lack of dorsomarginal kineties. They are all non-dorsomarginalian hypotrichs, and this clade is separate with Dorsomarginalia, all species of which have dorsomarginal row $[1,19,21,23-29]$. The result further proves the importance of dorsal structure in hypotrichous classification.

The sequence of the type species, $B$. buitkampi, is still unknown. Even though the phylogenetic position of $B$. granulifera n. sp. was shown in present work, the position of the genus Bistichella cannot be certain. Futhermore, only a few sequences of genera, which are morphological similar with Bistichella (Lamtostyla, Orthoamphisiella and Uroleptoides), are available, and the bootstrap values are very low in the phylogenetic tree, which is also seen previous work [22, 30-32]. Therefore, we cannot reach a conclusion of the phylogenetic relationship between Bistichella and its morphological similar genera. Further investigations with additional taxa and molecular data may reveal the evolution of Bistichella.

\section{Conclusions}

The morphology, morphogenesis and phylogeny of Bistichella granulifera $\mathrm{n}$. $\mathrm{sp}$. is described. In the phylogenetic tree, B. granulifera $\mathrm{n}$. $\mathrm{sp}$. has a close relationship with species which have three bipolar dorsal kineties, and a lack of dorsomarginal kineties. Therefore, Bistichella should belong to non-Dorsomarginalia. Also, further morphogenetic and molecular studies would help to confirm the phylogenetic position of Bistichella.

\section{Methods}

\section{Sampling and cultivation}


Bistichella granulifera $\mathrm{n}$. sp. was isolated from a soil sample which was collected on 17 April 2016 from a hill in Jiangjunshan ancient town $\left(34^{\circ} 02^{\prime} 16^{\prime \prime} \mathrm{N} ; 109^{\circ} 04^{\prime} 53^{\prime \prime} \mathrm{E}\right)$, Xi'an, China. Ciliates were stimulated to excyst and emerge from the soil sample using the nonflooded Petri dish method [18]. Cells were maintained in the raw cultures at room temperature (about $24^{\circ} \mathrm{C}$ ) using sterile water, with bacteria and mainly small ciliates as food sources. However, only a low number of cells were found. A clonal culture could not be established in the laboratory. The species was accurately identified based on its morphological and morphogenetic characteristics. Moreover, no other Bistichella specimens were present in the protargol preparations. Therefore, it is almost certain that all data is based on B. granulifera $\mathrm{n}$. sp.

\section{Morphology and morphogenesis}

Living cells were observed using bright field and differential interference contrast microscopy (Olympus BX52), and specimens were photographed using a digital camera. The protargol method was used to reveal the ciliature and the nuclear apparatus [33]. Counts and measurements of stained specimens were performed at a magnification of 1,000x. Drawings of stained cells were made with the aid of a camera lucida. To illustrate the changes occurring during morphogenesis process, ciliary structures of parental cirri and membranelles are depicted by contour lines, whereas new ones are shaded black [34]. Terminology is according to Berger (2008) [1].

\section{DNA extraction, PCR amplification, and sequencing}

A few cells of Bistichella granulifera $\mathrm{n}$. $\mathrm{sp}$. were isolated and repeatedly washed with sterilized distilled water. Genomic DNA was extracted from cells using DNeasy Blood \& Tissue Kit (Qiagen, CA) following the manufacturer's instructions. The SSU rDNA was amplified using the eukaryotic universal primers 18S-F and 18S-R [35]. The amplification cycles were according to previous work [36, 37]. High-fidelity Taq polymerase (Takara Ex Taq, Takara Biomedicals) was used to minimize the possibility of amplification errors. Sequencing of the PCR products was performed bidirectionally on an ABI 3700 sequencer (Invitrogen sequencing facility, Shanghai, China) using primers 18S-F, 18S-R and three internal primers 900F, 900R and Pro B [37].

\section{Phylogenetic analyses}

The SSU rDNA sequence of the Bistichella granulifera $\mathrm{n}$. sp. was aligned with sequences of 70 representative taxa downloaded from the GenBank database. Four species were selected as the outgroup species. The accession number of each species is mentioned in the phylogenetic tree (Fig. 5). Subsequently, all sequences were aligned using the GUIDANCE web server (http://guidance.tau.ac.il/) [38]. The resulting alignment was manually edited using the program BioEdit 7.0, which removed ambiguous regions and trimmed the ends [39]. Maximum likelihood (ML) analyses were performed online using RAXML-HPC2 on XSEDE v8.2.9 [40, 41] on the CIPRES Science Gateway [42]. The reliability of internal branches was assessed using a nonparametric bootstrap method with 1000 replicates. Bayesian inference (BI) was performed using MrBayes on XSEDE 3.2.6 [43] with the best-fit model GTR + I + G model as selected by Akaike Information Criterion (AIC) in MrModeltest v.2.0 [44]. Markov chain Monte Carlo simulations were run for 1000000 generations with a sampling frequency of 100 and a burn-in of 1000 trees. The remaining trees were used to calculate the posterior probabilities (PP) with a majority rule consensus. SeaView v.4 [45] and MEGA v7.0 [46] were used to visualize the tree topologies.

\section{Abbreviations}

AZM: adoral zone of membranelles; BI: Bayesian inference; bp: base pairs; GC: Guanine-cytosine; ML: Maximum likelihood; $n$. sp.: novum species; PCR: Polymerase chain reaction; SSU rDNA: Small subunit ribosomal DNA.

\section{Declarations}

\section{Ethics approval and consent to participate}

Not applicable.

\section{Consent for publication}

Not applicable.

\section{Availability of data and materials}


Sequence data are available in GenBank (Accession Numbers: MT604042). Three protargol slides have been deposited in the collection of the Laboratory of Protozoological Biodiversity and Evolution in Wetland, Shaanxi Normal University, China (accession numbers: LZ2016041701A-C).

\section{Competing interests}

The authors declare that they have no competing interests.

\section{Funding}

This work was financially supported by the Natural Science Foundation of China (Project number: 31872190). The funding bodies had no role in the design or implementation of this study or in preparation of the manuscript.

\section{Authors' contributions}

LZ collected the samples, did protargol preparations, and wrote the main part of the manuscript; LJ analyzed data and wrote some parts of the manuscript; WY extracted DNA and built the phylogenetic tree; MJ depicted infraciliature and provided the morphometric data; SC conducted the experiment and revised the manuscript. All the authors checked the manuscript before submission.

\section{Acknowledgements}

Many thanks are given to Mr. Dale Oyston for correcting the English of this paper.

\section{References}

1. Berger H. Monograph of the Amphisiellidae and Trachelostylidae (Ciliophora, Hypotricha). Monogr 2008;88:1-737.

2. Berger H. Monograph of the Gonostomatidae and Kahliellidae (Ciliophora, Hypotricha). Monogr Biol. 2011;90:1-741.

3. Bhartia D, Kumar S, Terza AL, Chandra K. Morphology and ontogeny of Tetmemena pustulata indica subspec. (Ciliophora, Hypotricha), from the Thane Creek, Mumbai, India. Eur J Protistol. 2019;71:125629.

4. Foissner W. Terrestrial and semiterrestrial ciliates (Protozoa, Ciliophora) from Venezuela and Galápagos. Denisia 2016;35:487-

5. Hu X, Lin X. Song W. Ciliates Atlas: Species Found in the South China Sea. Science Press (Beijing) 2019;p:1-

6. Luo X, Huang J, Li L, Song W, Bourland WA. Phylogeny of the ciliate family Psilotrichidae (Protista, Ciliophora), a curious and poorly-known taxon, with notes on two algae-bearing psilotrichids from Guam, USA. BMC Evolut Biol. 2019;19:125.

7. Song W, Shao C. Ontogenetic Patterns of Hypotrich Ciliates. Science Press (in Chinese). 2017;p:1-

8. Zhang T, Dong J, Cheng T, Duan L, Shao C. Reconsideration of the taxonomy of the marine ciliate Neobakuella aenigmatica Moon et al., 2019 (Protozoa, Ciliophora, Hypotrichia). Mar Life Sci Technol. 2020;2:97-

9. Chen L, Dong J, Wu W, Xin Y, Warren A, Ning Y, Zhao Y. Morphology and molecular phylogeny of a new hypotrich ciliate, Anteholosticha songi spec., and an American population of Holosticha pullaster (Müller, 1773) Foissner et al., 1991 (Ciliophora, Hypotrichia). Eur J Protistol. 2020;72:125646.

10. Dong J, Chen X, Liu Y, Ni B, Fan X, Li L, Warren A. An integrative investigation of Parabistichella variabilis (Protista, Ciliophora, Hypotrichia) including its general morphology, ultrastructure, ontogenesis, and molecular phylogeny. J Eukaryot Microbiol. 2020;doi:10.1111/jeu.12809.

11. Kaur H, Shashi, Negi RK, Kamra K. Morphological and molecular characterization of Neogastrostyla aqua gen., nov. spec. (Ciliophora, Hypotrichia) from River Yamuna, Delhi; comparison with Gastrostyla-like genera. Eur J Protistol. 2019;68:68-79.

12. Kim KS, Min GS. Morphology and molecular phylogeny of Oxytricha seokmoensis nov. (Hypotrichia: Oxytrichidae), with notes on its morphogenesis. Eur J Protistol. 2019;71:125641.

13. Jung JH., Berger H. Monographic treatment of Paraholosticha muscicola (Ciliophora, Keronopsidae), including morphological and molecular biological characterization of a brackish water population from Korea. Eur J Protistol. 2019;68:48-

14. Park KM, Jung JH, Jeong HK, Min GS, Kim S. Morphology, morphogenesis, and molecular phylogeny of a new freshwater ciliate, Gonostomum jangbogoensis sp. (Ciliophora, Hypotricha), from Victoria Land, Antarctica. Eur J Protistol. 2020;73:125669. 
15. Foissner W. Ökologie und Taxonomie der Hypotrichida (Protozoa: Ciliophora) einiger österreichischer Böden). Archiv Für Protistenkind 1982;126:19-143.

16. Gellért J. Ciliaten des sic hunter dem Moosrasen auf Felsen gebildeten Humus. Acta Biol Hung 1956;6, 337-359.

17. Aescht E. Annotated catalogue of "type material" of ciliates (Ciliophora) and some further protists at the Upper Austrian Museum in Linz (Austria) including a guideline for "typification" of species. Denisia 2008;23:125-234.

18. Foissner W. An update of 'basic light and scanning electron microscopic methods for taxonomic studies of ciliated protozoa'. Int $J$ Syst Evol Microbiol. 2014;64:271-

19. Fan Y, Hu X, Gao F, Al-Farraj SA, Al-Rasheid KAS. Morphology, ontogenetic features and SSU rRNA gene-based phylogeny of a soil ciliate, Bistichella cystiformans nov. (Protista, Ciliophora, Stichotrichia). Int J Syst Evol Microbiol. 2014;64:4049-4060.

20. He Y, Xu K. Morphology and small subunit rDNA phylogeny of a new soil ciliate, Bistichella variabilis sp. (Ciliophora, Stichotrichia). J Eukaryot Microbiol. 2011;58:332-338.

21. Jiang J, Huang J, Li L, Shao C, Al-Rasheid KAS, Al-Farraj SA, Chen Z. Morphology, ontogeny, and molecular phylogeny of two novel bakuellid-like hypotrichs (Ciliophora: Hypotrichia), with establishment of two new genera. Eur J Protistol. 2013;49:78-92.

22. Lyu Z, Li J, Shao C. Redescription of the soil hypotrichous ciliate, Parabistichella dieckmanni (Foissner, 1998) Foissner, 2016 (Ciliophora, Hypotrichia), with notes on its morphogenesis and phylogeny. J Eukaryot Microbiol. 2020;

23. Dong J, Li L, Fan X, Ma H, Warren A. 2020. Two Urosoma species (Ciliophora, Hypotrichia): A multidisciplinary approach provides new insights into their ultrastructure and systematics. Eur J Protistol. 2020;72:125661.

24. Lu X, Wang Y, Al-Farraj SA, El-Serehy H, Huang J, Shao C. The insights into the systematic relationship of Gastrostyla-affinitive genera, with report on a new saline soil ciliate genus and new species (Protozoa, Ciliophora). BMC Evolut Biol. 2020;in press.

25. Luo X, Yi Z, Gao F, Pan Y, Al-Farraj SA, Warren A. Taxonomy and molecular phylogeny of two new brackish hypotrichous ciliates, with the establishment of a new genus (Protozoa, Ciliophora). Zool J Linn Soc. 2016;179:475-491

26. Ma J, Zhao Y, Zhang T, Shao C, Al-Rasheid KAS, Song W. Cell-division pattern and phylogenetic analyses of a new ciliate genus Parasincirra g. (Protista, Ciliophora, Hypotrichia), with a report of a new soil species, $P$. sinica n. sp. from northwest China BMC Evolut Biol. 2020;in press.

27. Shao C, Hu C, Fan Y, Warren A, Lin X. Morphology, morphogenesis and molecular phylogeny of a freshwater ciliate, Monomicrocaryon euglenivorum euglenivorum (Ciliophora, Oxytrichidae). Eur J Protistol. 2019;68:25-36.

28. Wang J, Li J, Qi S, Warren A, Shao C. Morphogenesis and molecular phylogeny of a soil ciliate Uroleptoides longiseries (Foissner, Agatha and Berger, 2002) Berger, 2008 (Ciliophora, Hypotrichia). J Eukaryot Microbiol. 2019;66:334-342.

29. Xu W, Zhao Y, Pan B, Liu Y, Li Y, Bourland, WA, Luo X. 2020. Morphology, morphogenesis, and phylogeny of Urosoma caudata (Ehrenberg, 1833) Berger, 1999 (Ciliophora, Hypotrichia) based on a Chinese population. J Eukaryot Microbiol. 2020;67:76-85.

30. Luo X, Yan Y, Shao C, Al-Farraj SA, Bourland WA, Song W. Morphological, ontogenetic and molecular data support strongylidiids as being closely related to Dorsomarginalia (Protozoa, Ciliophora) and reactivation of the family Strongylidiidae Fauré-Fremiet, 1961. Zool J Linn Soc. 2018;184:237-

31. Park KM, Chae N, Jung JH, Min GS, Kim S, Berger H. Redescription of Keronopsis helluo Penard, 1922 from Antarctica and Paraholosticha pannonica Gellért and Tamás, 1959 from Alaska (Ciliophora, Hypotricha). Eur J Protistol. 2017;60:102-118.

32. Dong J, Lu X, Shao C, Huang J, Al-Rasheid KA. S. Morphology, morphogenesis and molecular phylogeny of a novel saline soil ciliate, Lamtostyla salina sp. (Ciliophora, Hypotricha). Eur J Protistol. 2016;56:219-231.

33. Wilbert N. Eine verbesserte technik der Protargolimprägnation für ciliaten. Mikrokosmos 1975;64:171-179.

34. Wang J, Li J, Shao C. Morphology, morphogenesis, and molecular phylogeny of a novel saline soil ciliate, Heterourosomoida sinica sp. (Ciliophora, Hypotrichia). Eur J Protistol. 2020;73:125666.

35. Medlin L, Elwood HJ, Stickel S, Sogin ML. The characterization of enzymatically amplified eukaryotic 16S-like rRNA-coding regions. Gene 1988;71:491-499.

36. Lyu Z, Wang J, Huang J, Warren A, Shao C. Multigenebased phylogeny of Urostylida (Ciliophora, Hypotrichia), with establishment of a novel family. Zool Scr. 2018;47:243-254.

37. Wang J, Zhao Y, Lu X, Lyu Z, Warren A, Shao C. Does the Gonostomum-patterned oral apparatus in hypotrichia carry a phylogenetic signal? Evidence from morphological and molecular data based on extended taxon sampling using three nuclear genes (Ciliophora, Spirotrichea). Sci China Life Sci. 2020;63:https://doi.org/10.1007/s11427-020-1667-3.

Page $11 / 16$ 
38. Penn O, Privman E, Ashkenazy H, Landan G, Graur D, Pupko T. GUIDANCE: a web server for assessing alignment confidence scores. Nucleic Acids Res. 2010;38:W23-W28.

39. Hall TA. BioEdit: a user-friendly biological sequence alignment editor and analysis program for Windows $95 / 98 /$ NT. Acids Symp Ser. 1999;41:95-98.

40. Stamatakis A. RAxML version 8: a tool for phylogenetic analysis and post-analysis of large phylogenies. Bioinformatics 2014;30:1312-1313.

41. Stamatakis A, Hoover P, Rougemont J. A rapid bootstrap algorithm for the RAxML web-servers. Syst Biol. 2008;57:758-771.

42. Miller MA, Pfeiffer W, Schwartz T. Creating the CIPRES science gateway for inference of large phylogenetic trees. In: Proceedings of the Gateway Computing Environments Workshop (GCE), New Orleans, LA. 2010;1-8.

https://doi.org/10.1109/GCE.2010.5676129.

43. Ronquist F, Teslenko M., van der Mark P, Ayres DL, Darling A, Höhna S, Larget B, Liu L, Suchard MA, Huelsenbeck JP. MrBayes 3.2: efficient Bayesian phylogenetic inference and model choice across a large model space. Syst Biol. 2012;61:539-542.

44. Nylander JAA. 2004. MrModeltest, Version 2.2. Program distributed by the author. Evolutionary Biology Centre, Uppsala University,

45. Gouy M, Guindon S, Gascuel O. SeaView version 4: a multiplatform graphical user interface for sequence alignment and phylogenetic tree building. Mol Biol Evol. 2010;27:221-224.

46. Tamura K, Peterson D, Peterson N, Stecher G, Nei M, Kumar S. MEGA5: molecular evolutionary genetics analysis using maximum likelihood, evolutionary distance, and maximum parsimony methods. Mol Biol Evol, 2011;28:2731-2739.

\section{Figures}
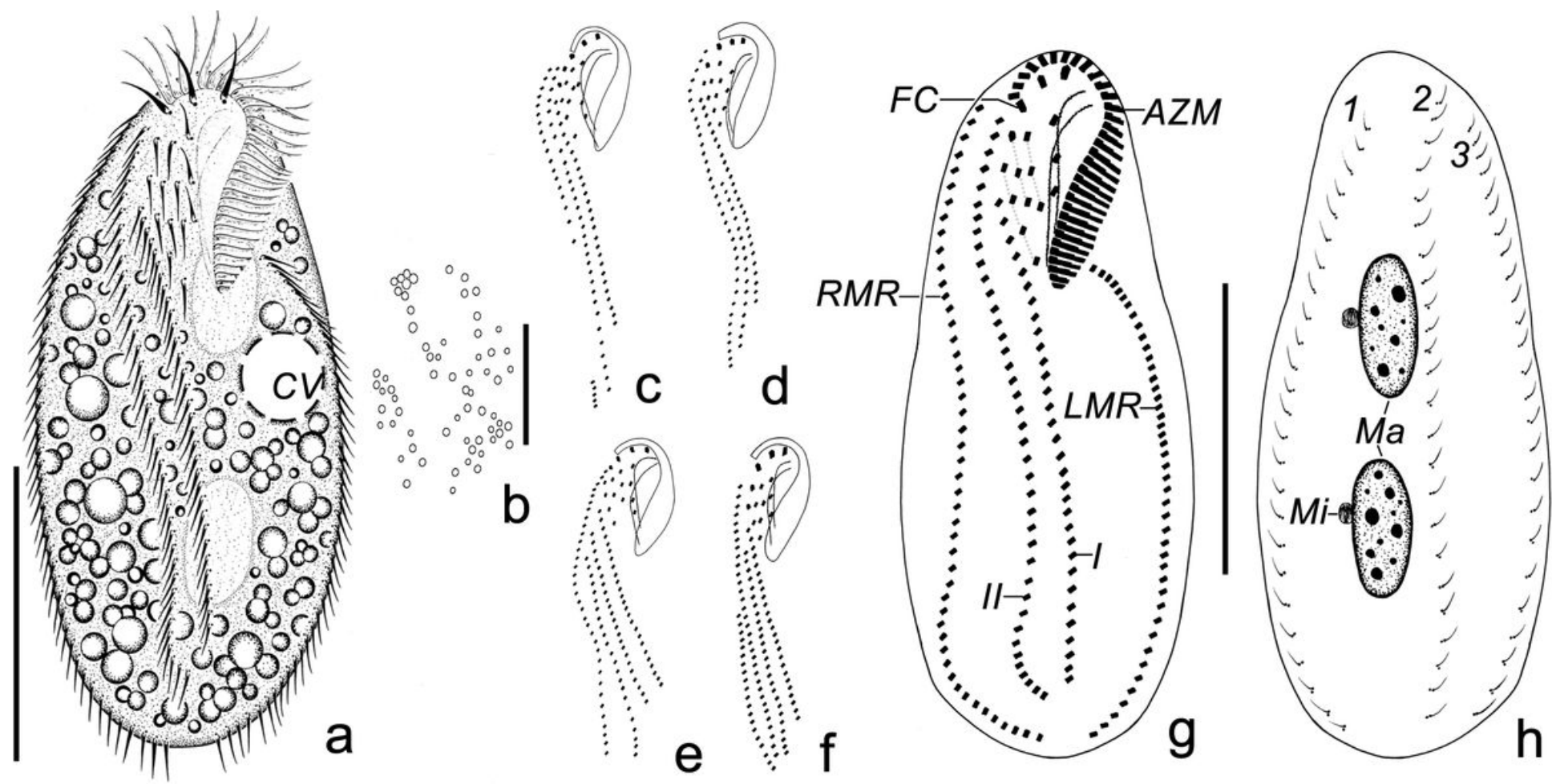

Figure 1

a-h. Morphology of Bistichella granulifera n. sp. from life (a) and after protargol staining (b-g). (a) Ventral view of a representative individual. (b-e) Ventral views of some other specimens to show the variety in the infraciliature. (f, g) Ventral (f) and dorsal (g) view of the holotype to show the infraciliature and nuclear apparatus. Dotted lines connect cirri in frontal rows. AZM, adoral zone of membranelles; FC, frontal cirri; LMR, left marginal row; Ma, macronuclear nodules; Mi, micronuclei; RMR, right marginal row; I, II, frontoventral rows I and Il; 1-3, dorsal kineties. Scale bars $=50 \mu \mathrm{m}(\mathrm{a}, \mathrm{g}, \mathrm{h}) ; 10 \mu \mathrm{m}(\mathrm{b})$. 

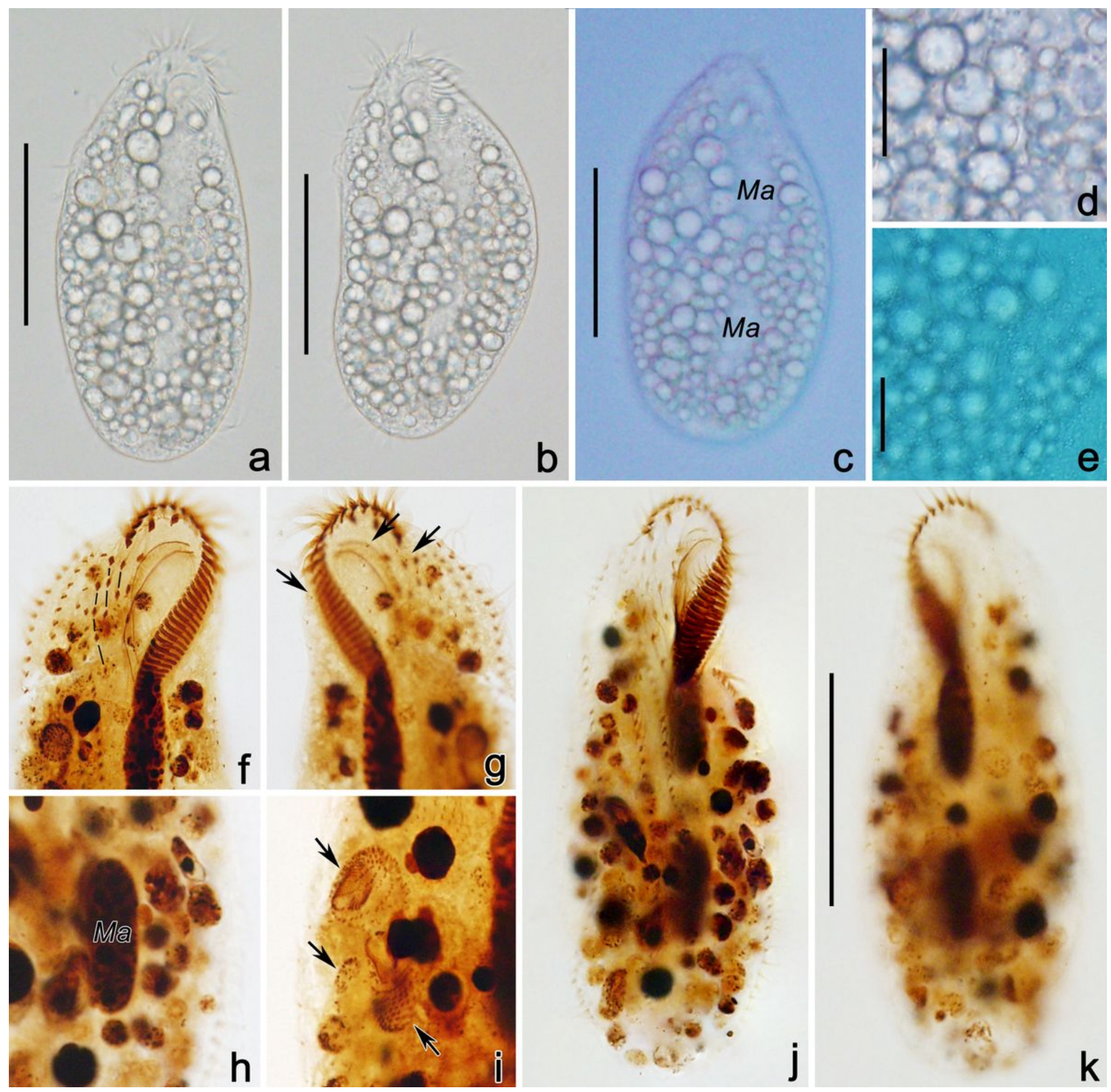

Figure 2

$a-k$. Microphotographs of Bistichella granulifera n. sp. from life $(a-e)$ and after protargol impregnation ( $f-k)$. (a-c) Ventral views of typical individuals, showing the different body shapes. (d) Cytoplasm with many food vacuoles and lipid droplets. (e) Cortical granules densely scattered throughout cell surface. (f) Ventral view of the anterior portion, dash lines show three short frontal cirral rows. (g) Dorsal view of the anterior portion, arrows demonstrate three dorsal kineties. (h) Macronuclear nodule. (i) Some small ingested ciliate (arrows). (j, k) Ventral (j) and dorsal (k) view of holotype specimen, showing infraciliature and nuclear apparatus. Scale bars $=50 \mu \mathrm{m}(a-c, j, k) ; 10 \mu \mathrm{m}(\mathrm{d}, \mathrm{e})$. 

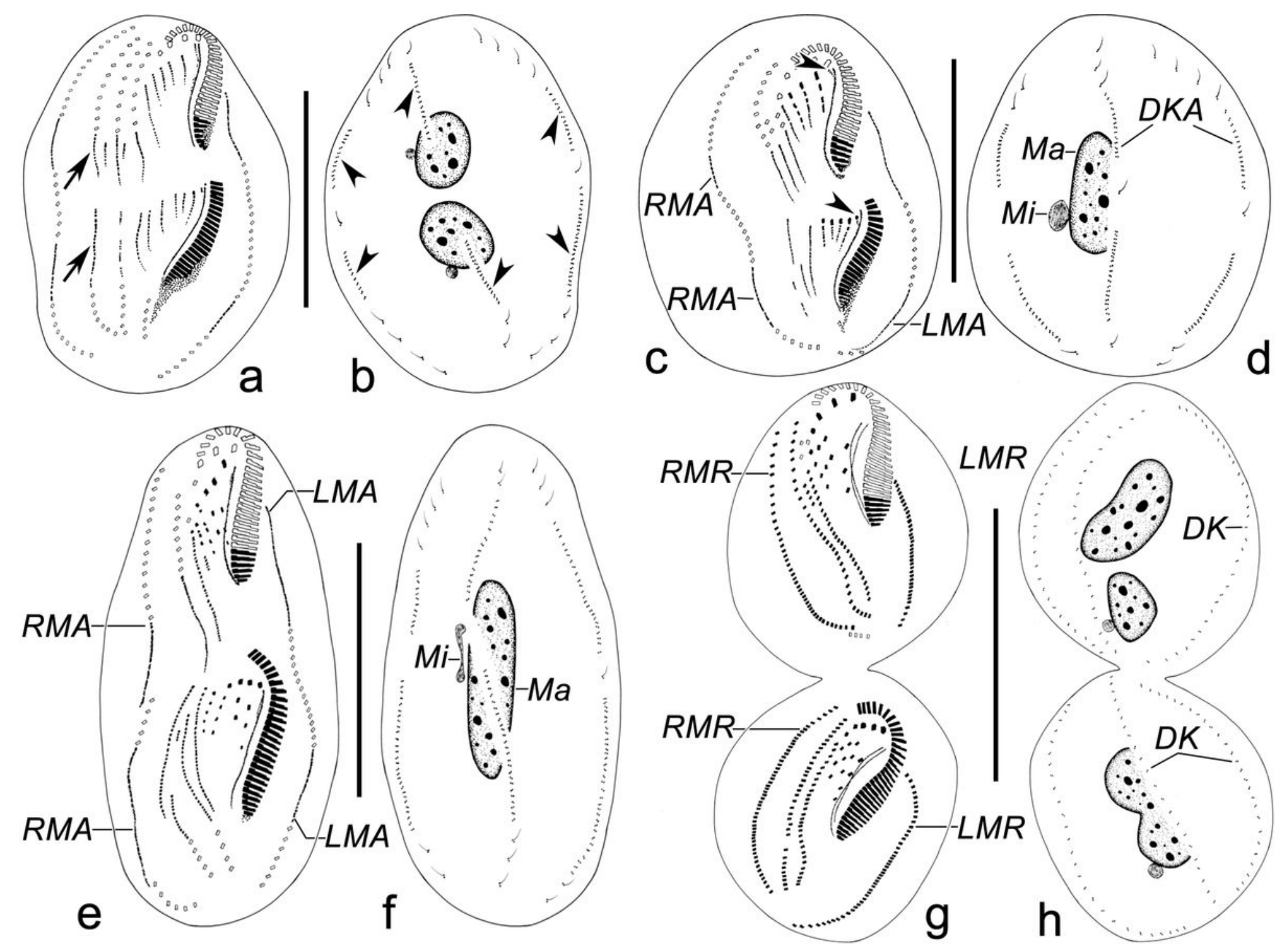

Figure 3

a-h. Morphogenesis of Bistichella granulifera $n$. sp. after protargol staining. (a, b) Ventral and dorsal view of an early divider, showing the formation of the frontoventral-transverse cirral anlagen (arrows). Note the proximal end of the old adoral zone of membranelles dedifferentiate and form the new membranelle, as well as marginal and dorsal kineties anlagen (arrowheads in b) develop intrakinetally. (c, d) Ventral and dorsal view of a middle divider, depicting formation of the leftmost frontal cirri (arrowheads), frontoventral-transverse cirral anlagen beginning to differentiate into cirri, and macronuclear nodules fused into a single mass. (e, $f$ ) Ventral and dorsal view of a middle divider, to demonstrate anlagen differentiated into cirri, the new adoral membranelles completed in the opisthe, and micronuclei divide mitotically. $(\mathrm{g}, \mathrm{h}$ ) Ventral and dorsal view of a late divider, marking the new cirri migrating into their final positions, undulating membranes anlagen longitudinally splitting into parorals and endorals, and the macronuclear nodules divided. DK, dorsal kineties; DKA, dorsal kineties anlagen; LMA, left marginal anlage; LMR, left marginal row; Ma, macronuclear nodules; Mi, micronuclei; RMA, right marginal anlage; RMR, right marginal row. Scale bars $=80 \mu \mathrm{m}$. 

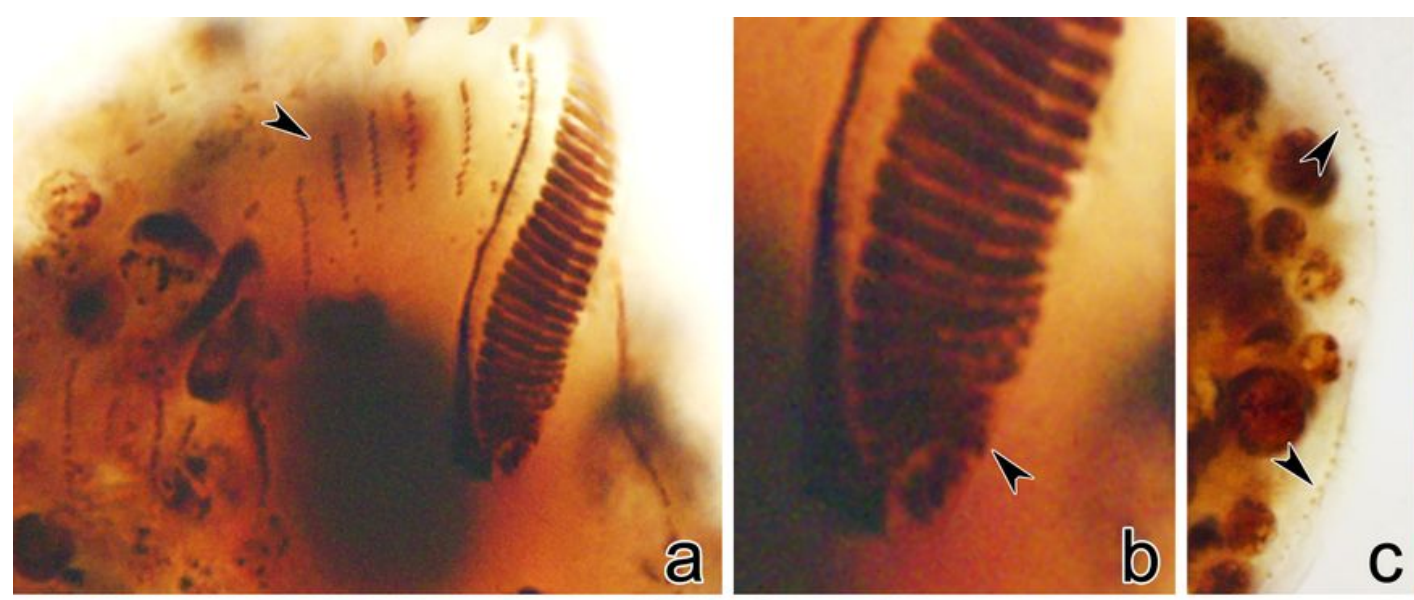

C
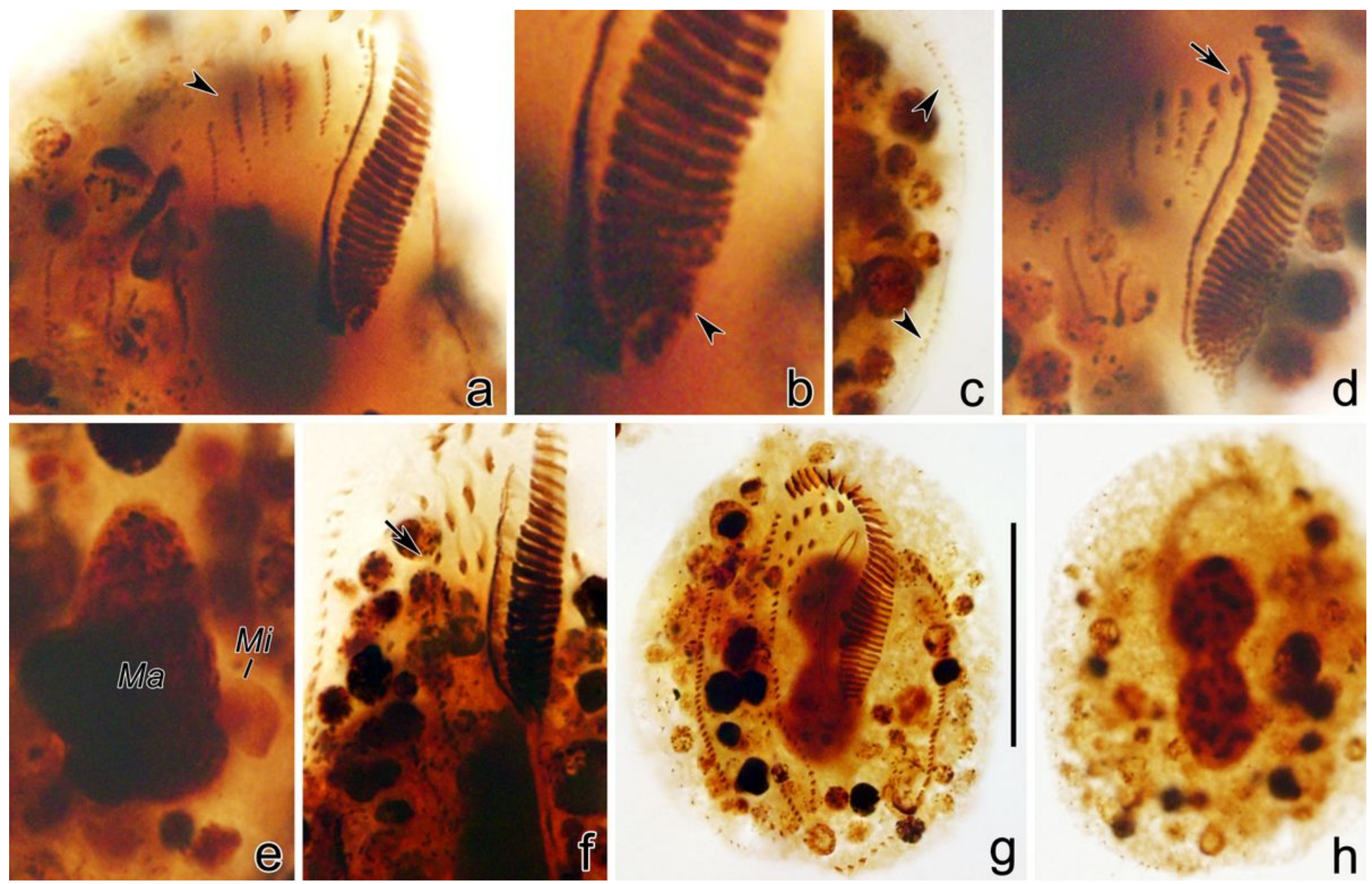

Figure 4

a-h. Photomicrographs of Bistichella granulifera $n$. sp. during morphogenesis after protargol staining (a-h). (a) Ventral view of an early divider to show the frontoventral-transverse cirral anlagen formed (arrowhead). (b) The old adoral zone of membranelles start to dedifferentiate and form the new membranelles (arrowhead). (c) Dorsal kineties develop intrakinetally (arrowheads). (d) Ventral view of a middle divider, showing that the first frontal cirrus originates from the undulating membranes anlage (arrow), the frontoventraltransverse cirral anlagen differentiate into cirri and the new adoral membranelles differentiate posteriad in the opisthe. (e) Macronuclear nodules fuse into a single mass. (f) Ventral view of a middle divider demonstrating the almost completed segmentation of the frontoventral-transverse cirral anlagen (arrow). $(\mathrm{g}, \mathrm{h}$ ) Ventral and dorsal view of a late divider, to depict cirri migrating into their final positions. Ma, macronuclear nodules; Mi, micronuclei. Scale bars $=30 \mu \mathrm{m}$. 


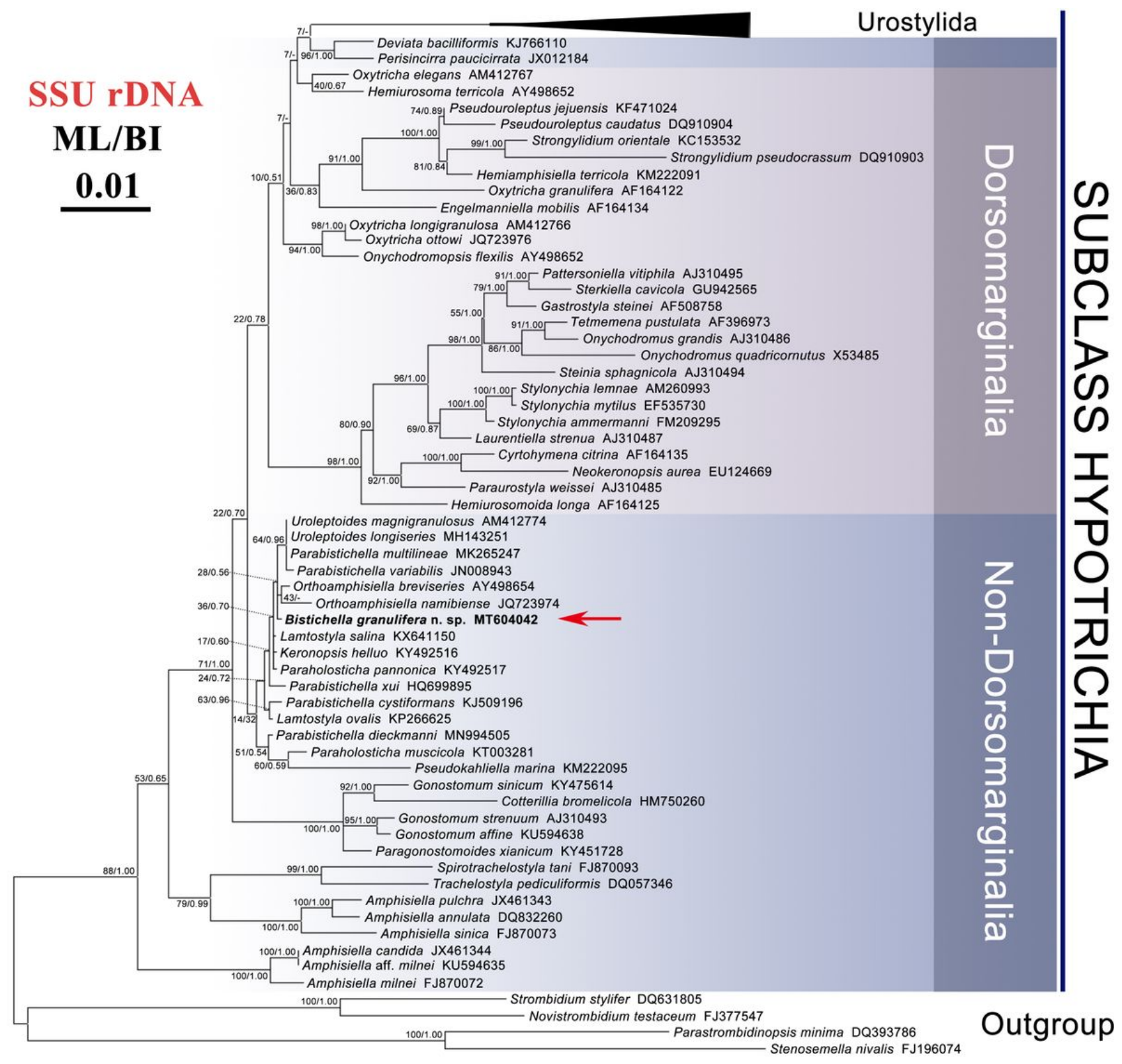

Figure 5

Maximum likelihood (ML) tree inferred from the SSU rDNA sequences showing the systematic position of Bistichella granulifera $\mathrm{n}$. $\mathrm{sp}$. (in bold). Numbers near nodes are bootstrap values for maximum-likelihood and posterior probability values for Bayesian inference (BI). "-" at nodes indicate disagreement between the two methods. The scale bar corresponds to 0.01 expected substitutions per site. 